\title{
RECENT DEVELOPMENTS IN EAST-WEST TRADE: THE U.S. PERSPECTIVE
}

\author{
A. Peter Parsons*
}

Upon his return from the May, I972, Moscow Summit Conference, President Nixon announced that groundwork had been laid for a comprehensive trade agreement with the Soviet Union. Shortly thereafter in October, I972, the Soviet Union and the United States signed agreements on trade ${ }^{1}$ and on settlement of the former's long-outstanding lend lease debt. ${ }^{2}$ The new agreements include new understandings between the parties on formerly insurmountable obstacles such as the Soviet repayment of lend lease indebtedness, the extension of reciprocal credits by instrumentalities of each party, the extension of most-favored-nation status to the Soviet Union, and sundry other provisions that have stood in the path of normalized trade relations for two and a half decades. The proposed Trade Reform Act of 1973 introduced by the Administration in April, 1973, would provide the requisite congressional approval for implementing the trade agreement's provisions concerning the grant of most-favored-nation status and the removal of discriminatory tariffs currently levied upon the importation of Soviet goods. ${ }^{3}$ Upon approval by Congress, the bill will signal the end of twenty-five years of artificially proscribed commercial relationships between the world's two largest economies.

Until very recently, the subject of East-West trade has been evidenced by a great deal of legal writing and very little actual trade. After World War II, the trade policy of the United States with regard to communist countries remained virtually unchanged for more than two decades. During this period the Soviet Union and the countries that comprise the "Soviet bloc" turned to ready markets in Western Europe, Great Britain, Japan, and elsewhere. In recent years, however, due to recurring Soviet crop failures, the United States, as the world's largest producer of grain, has negotiated several large grain sales, but these sporadic shipments can hardly be characterized as an ongoing commercial relationship. The future prospect of a more enduring trade relation has required extensive readjustment of the legal framework in which these new commercial arrangements will be undertaken.

\footnotetext{
*B.S., Florida Atantic University, 1969; J.D., Duke University, I973.

${ }^{1}$ See text of the AGREement WITH THE GovernMent of THE UNION of Soviet Socialist Repunlics Regarding Trade reprinted in 67 Dep'T State Bull. 595 (1972) [hereinafter cited as US-USSR AgreeMENT]. An excellent detailed treatment of the US-USSR AGREEMIENT is contained in Starr, A NetU Legal Framework for Trade Between the United States and the Soviet Union: The 1972 US-USSR Trade Agreement, 67 AM. J. INT'L L. 63 (I973).

3 The importance of the lend lease settlement cannot be overstated. For many members of Congress, its settlement was a mandatory predicate to any liberalization of Soviet-U.S. trade policy. See text of the Agremant with the Government of tFe Union of Soviet Socialist Republics Regarding SettifeMENT of LeNd Lease, Reciprocal AId and Claims reprinted in 67 Dep't State Bul.. 603 (1972).

${ }^{8}$ H.R. 6767 , 93d Cong., Ist Sess. (1973).
} 


\section{Changes in Export Import Legislation}

\section{A. Export Controls}

Subject to popular pressures, American policy on East-West trade has never been distinguished by clarity or logical consistency. After World War II the Congress, mindful of the recent wartime shortages, re-enacted the then-existing emergency export control legislation on a year-to-year basis until 1949. ${ }^{4}$ In that year, Congress passed the Export Control Act, the most comprehensive piece of export legislation enacted to date. The Act granted the President authority to control or even terminate any or all United States exports on the elusive grounds of "foreign policy" or "national security." At the time of enactment, the Congress was concerned with the conservation of scarce commodities and avoiding exportation of goods that would contribute to the military or economic development of the communist countries. The Act provided for control of exports to various countries by imposing licensing requirements upon exporters. Since then, licensing procedures and regulations have created an impenetrable bureaucratic thicket that would deter all but the most sophisticated or stalwart of exporters. ${ }^{6}$ 'The I949 Act, first enacted as a temporary measure with successive extensions in I95I, I953, I956, I958, I960, I962, and I965, governed the foreign commerce of the United States for two decades.

Concern over strategic exports to Eastern Europe led to the Mutual Assistance Control Act of I95I, also known as the Battle Act, under which embargoes on certain strategic commodities are coordinated with our allies. ${ }^{7}$ During the forties and early fifties when European industrial capacity was severely limited, the export controls over certain commodities were thought to have a retarding effect upon the economic and military growth of world communism. However, during the later part of the fifties and sixties, it became increasingly apparent that the communist countries were able to secure needed industrial and agricultural products from eager suppliers elsewhere. ${ }^{8}$ The only notable result of our restrictive export practices appeared to be an indirect subsidy of Western European industry at the expense of our own producers and their foreign subsidiaries.

The Export Administration Act of 1969 represented a major shift in the approach to exports bound for communist countries. ${ }^{10}$ The I969 Act removed much of the

\footnotetext{
"For a summary of export controls through r949 see Note, Export Controls, 58 YALE L.J. 1325 (1949).

'Export Control Act of I949, ch. II, 63 Stat. 7, as amended 50 U.S.C. $\$ \$ 202$ I-32 (I964) (expired

Dec. 3I, 1969). See generally Berman \& Garson, United States Export Controls-Past, Present, and Future, 67 Colum. L. Rev. 791 (1967).

- See Berman \& Garson, Possible Effects of the Proposed East-West Trade Relations Act Upon U.S. Import, Export and Credit Controls, 20 VAND. L. Rev. 279, 287 (I967).

722 U.S.C. $\$ \$ \mathrm{x} 6 \mathrm{I} \mathrm{I}-\mathrm{I} 3 \mathrm{~d}(\mathrm{Ig70})$.

${ }^{8}$ See, e.g., Berman \& Garson, supra note 5 , at 876 .

'See Brush, Implementation of the Export Administration Act of 1969, 4 CoNN. L. REv. 35 (I97I); Note, Export Controls-A National Security Standard?, I2 VA. J. INr'L L. 92, I01-03 (I97I).

${ }^{10} 50$ U.S.C. $\$ \S 240 \mathrm{I}-13$ (1970), as amended 50 U.S.C.A. App. $\$ \$ 240 \mathrm{I}-13$ (Supp. 1973).
} 
negativism that had theretofore surrounded export controls. It declared that United States policy is, "to encourage trade with all countries with which we have diplomatic or trading relations ...," excepting only trade with countries that the President has found to be against the national interest or exports "which would make a significant contribution to the military potential of any nation ... or ... prove detrimental to the national security ...." ${ }^{\text {"11 }}$ Conspicuously absent in the language of the Act are provisions that restrain trade in commodities that may have an economic effect upon the recipient country. There remains, however, as a legacy of the 1949 Act a labyrinth of regulations and burdensome licensing requirements. ${ }^{12}$ At least for the near future, the r 969 Export Administration Act represents a cosmetic shift in policy rather than a substantial impetus to East-West trade.

\section{B. Import Barriers}

Discriminatory tariffs levied upon communist goods constitute further impediments to the development of East-West trade. ${ }^{13}$ Anti-communist tariff walls, like their export control counterparts, were thought to have a retardant effect upon the spread of communism. Unable to avail itself of American markets, the Soviet bloc countries have found Great Britain, Japan, and the countries of Western Europe quite compatible trading partners.

Inevitably, trade between the United States and the East will be tied to balance of payment considerations. Although current and contemplated future trade with the Soviets will heavily favor the United States, the East European countries cannot tolerate a trade deficit indefinitely. There are many Soviet products for which there is a continuing American demand, such as crabmeat, timber, chemicals, and furs. It is doubtful, however, whether the United States could import enough of these items to create a parity in imports and exports. A potential source of parity would be increased U.S. importation of the Soviet Union's vast resources of raw materials, already in high demand by American industry. However, substantial pre-emption of this considerable Soviet export market by the United States could present severe ideological problems. It may be assumed that the Soviets will not be quick to export a major portion of their share of the world's dwindling natural resources as grist for the mills of the capitalist West. On the other hand, the American consumer may have a difficult moral adjustment to make before there is a widespread acceptance of commodities of communist origin. Also, the business community (which is gen-

\footnotetext{
${ }^{11} 50$ U.S.C. $\$ 2402(x)$ (1970) (emphasis added).

12 See S. Pisar, Coexistence and Commerce: Guidelines for Transactions Between East and West 123 (1970) [hereinafter cited as PISAR]; Brush, supra note 9, at 52; Note, supra note 9, at Ix3-19.

${ }_{13}$ The principal countries whose exports are subjected to the discriminatory rates are Albania, Bulgaria, China, Cuba, Czechoslovakia, East Germany, Hungary, communist controlled portions of Southeast Asia, Rumania, North Korea, and the U.S.S.R. Tariff Act of 1930 , I9 U.S.C. $\$ 1202(3)$ (c) (1970). Notably excluded from the discriminatory treatment of this statute and the sanction of the Trade Expansion Act of 1962 are Poland and Yugoslavia to which most-favored-nation status has been extended pursuant to a determination by the President that such trade was "important to the national interest and would promote the independence of such country or area from domination or control by international communism ...." Id. $\S \mathrm{r} 86 \mathrm{r}(\mathrm{b})$.
} 
erally a rather conservative segment of our society) may have difficulty finding sufficient motivation to deal with a communist agency that represents, to them, the antithesis of cherished capitalist ideals. ${ }^{14}$

On a long-term basis, it can be assumed that the planned economies would channel their factors of production to meet American demands. However, at present communist commodities meet severe obstacles as they enter the United States market place. Although the United States tariff system has been revised, it still flatly discriminates against goods of communist origin. Imports from the East are subject to tariffs which are invariably at least twice that imposed upon an identical item imported from a non-communist country. ${ }^{15}$

Upon passage of the proposed Trade Reform Act of 1973, the President would be empowered to extend most-favored-nation status to the Soviet Union, thereby eliminating our current exclusionary tariff walls. ${ }^{16}$ As previously discussed, the lessening of tariffs will not result in a glut of Soviet goods upon the United States market place. Current forecasts predict trade balances will continue to favor the United States by a ratio of three to one, with Soviet purchases expected to aggregate at least \$r.5 billion in the period I972-74. ${ }^{17}$ At present, then, increased trade with the Soviets will be important in diminishing the now chronic balance of payments problem of the United States, and the elimination of U.S. tariffs would not seem to represent a threat to the American economy.

\section{The Export-Import Bank}

The Export Expansion Finance Act of $197 \mathrm{I}$ introduced a vehicle with a sizeable potential for spurring an increase in export commerce. ${ }^{18}$ The I97I Act amends the Export-Import Bank ("Eximbank") Act of 1945, which created a public governmental corporation to aid in the financing of imports and exports. Unfortunately, the Bank has been subject to various countervailing political pressures. In the mid-

\footnotetext{
${ }^{14}$ See Bilder, East-West Trade Boycotts: A Study in Private, Labor Union, State, and Local Interference with Foreign Policy, Ir8 U. PA. L. REv. 84I, 850-5I (1970).

${ }^{16}$ Examples of prohibitive tariff rates are abundant; however, a few examples are listed below:

Commodity

Whole Chicken

Vodka

Canned Tuna

Spruce Pine Lumber

Cheddar, Edam, Gouda, or Blue Cheeses

Eggs

Communist Rate

Io\& per lb.

$\$ 5.00$ per gal.

$25 \%$ ad valorem

$\$ 4.00$ per $\mathrm{r}, 000 \mathrm{ft}$.,

bd. measure

$35 \%$ ad valorem

ro $\$$ per dozen

It must be noted that there are a few areas such as in specific agricultural commodities where the communist countries are given equal tariff treatment. Ig U.S.C. $\$$ I202 (I970).

${ }^{10}$ H.R. 6767 , tit. V, 93 d Cong., Ist Sess. (1973).

${ }^{17}$ White House Fact Sheet, 67 Dep'T State Bull. 592, 593 (I973) [hereinafter cited as White House Fact Sheet].

${ }^{18}$ Pub. L. No. 92-126; 85 Stat. 345 (partially codified at 12 U.S.C.A. $\$ 635$ (Supp. 1973), amending I2 U.S.C. $\$ 635$ (1970)).
} 
sixties, the Bank was prohibited from granting credit for the sale or lease of goods to a communist country or if the goods were known to be ultimately destined for use in a communist country, unless the President determined the transaction was in the national interest. ${ }^{19}$ A further blow was dealt to East-West trade in 1968 when the Bank was absolutely prohibited from extending credit to any country which traded with a country in armed conflict with the United States. ${ }^{20}$ This provision had the practical effect of preventing the Bank from participating in the financing of exports to any communist country. The 197 Export Expansion Act may signal an awakening in the Congress to the potential of the East European markets. The Act was fostered by a growing concern over the increasing balance of payments deficit and dwindling export surpluses. In its report, the House Banking and Currency Committee noted that few of our allies distinguished between communist and noncommunist countries in the granting of export credit, and that while trade with Eastern Europe comprised sixteen per cent of the world market, the United States' share was only three per cent of that total. ${ }^{21}$ The expansion of American export trade was being seriously restricted by monetary and statutory limitations placed upon the Eximbank and voluntary limitations imposed upon private commercial banks by the Federal Reserve System. ${ }^{22}$ To expand trade financing, the Act raises the ceiling of loan guarantees to $\$$ ro billion, an increase from $\$ 3.5$ billion, and the ceiling on all financial activity to $\$ 20$ billion from the former $\$ 13.5$ billion level. ${ }^{23}$ The $x 968$ absolute prohibition on extension of credit to communist countries not in armed conflict with the United States is abolished. Such assistance is subject only to a presidential determination that a particular transaction or trade with a specific communist country would be in the national interest. ${ }^{24}$

The October 1972 Agreement on trade included a provision for reciprocity in the extension of trade credits by the Eximbank and the Foreign Trade Bank of the Soviet Union. In addition, American business concerns will be eligible for the advancement of credit from forty state trading organizations. ${ }^{25}$ Accordingly, President Nixon has entered his determination that it is in the national interest for the Eximbank to participate in the financing of exports to the Soviet Union. ${ }^{28}$ Thus, by amendment and presidential determination the entire thrust of the r945 Act has changed from total prohibition to positive inducement.

\footnotetext{
${ }^{10}$ I964 Foreign Aid and Related Appropriations Act, tit. III, Pub. L. No. 88-258, 77 Stat. 862, as amended Act of Mar. I3, rg68, Pub. L. No. 90-267, $\S$ I(c), 82 Stat. 47-49. See generally Pisar ro8-ri; Berman \& Garson, supra note 6, at 297.

${ }^{20}$ Act of Mar. 13, I968, Pub. L. No. 90-267, § I(c), 82 Stat. 47-49. See generally Pisan Iro.

21 H.R. REP. No. 303, 92d Cong., Ist Sess. 7 (I97I).

s2 The Federal Reserve System in 1965 embarked upon a Voluntary Foreign Credit Restraint (VFCR) program, the effect of which was to place a ceiling on loans to foreigners approximately equivalent to a percentage of bank assets or the value of such loans at the end of 1964 . The Export Expansion Act of $x 971$ specifically calls for a halt to the VFCR practice. Pub. L. No. 92-126, \$2, 85 Stat. 345 .

${ }^{23} 12$ U.S.C.A. $\$ 635$ (Supp. 1973).

24 I2 U.S.C.A. $\$ 635$ (b) (2) (Supp. 1973).

25 White House Fact Sheet at 593 .

26 Presidential Determination No. 72-I8roo, 37 Fed. Reg. 22573 (1972).
} 
II

\section{Settlement of Commercial Disputes}

\section{A. Arbitration}

Soviet insistence upon mandatory arbitration under Soviet law has, in the past, led to a considerable hesitancy on the part of Western businessmen to deal with the various state trading organizations. The Soviets view arbitration as a desirable alternative to the "bourgeois" courts of the West. The Foreign Trade Arbitration Commission (FTAC) of the All-Union Chamber of Commerce of the U.S.S.R., established in 1932 , is the sole Soviet mechanism for arbitration with the commercial entities of other nations. ${ }^{27}$ Due to the relative paucity of Soviet-American trade, there is little substantive law regarding the treatment of the FTAC by our domestic courts. The notable decision of Amtorg Trading Corp. v. Camden Fibre Mills, Inc. ${ }^{28}$ wherein an American purchaser fearing unfair treatment by the FTAC sought to have the arbitration provisions in its contract with Amtorg set aside, has been widely accepted as standing for the proposition that Soviet arbitration is not per se violation of public policy. The New York Court of Appeals affirming the lower court noted,

Camden chose to do business with Amtorg and to accept, as one of the conditions imposed, arbitration in Russia; it may not now ask the courts to relieve it of the contractual obligation it assumed. ${ }^{29}$

The decision of the New York court was quite favorably received by commentators, and future FTAC arbitration provisions and enforcement of awards appear to face no obstacle in New York courts. ${ }^{30}$

Arbitration was one of the major subjects of the October 1972 Trade Agreement. A provision of the Agreement provides for third party country arbitration of disputes between state trading companies and U.S. commercial organizations, with American businesses and their Soviet trading partners choosing a mutually satisfactory country. In absence of an agreement providing to the contrary, arbitration will be conducted in a country other than the U.S. or the U.S.S.R. under the arbitration Rules of the Economic Commission for Europe. ${ }^{31}$ Thus with regard to arbitration, a United States enterprise is no longer confronted with FTAC arbitration as a mandatory concomitant of East-West trade.

\section{B. The Legal Status of East-West Trading Concerns}

The jural status of Eastern state trading organizations in the United States has been rarely called into controversy. American courts have generally subscribed to

\footnotetext{
${ }^{27}$ Leff, The Foreign Trade Arbitration Commission of the USSR and the West, 24 ARB. J. (n.s.) I, 2 (1969).

${ }^{38} 304$ N.Y. 5I9, I09 N.E.2d 606 (I952).

s0 Id. at 52I, I09 N.E.2d at 607. However, the court left the door open to the American company should the FTAC proceedings be unfair. Id. at 52I, I09 N.E.2d at 608 .

${ }^{30}$ See, e.g., Pisar 465 ; Hazard, State Trading and Arbitration in International Trade Arbitration 93 (M. Domke ed. 1958).

${ }^{31}$ US-USSR AGREEMENT, art. 7 .
} 
a theory of restrictive sovereign immunity in dealing with the instrumentalities of foreign governments. Therefore, although a state trading organization is an extension of a foreign government, the nature of its activities strips it of a governmental character. Hence, sovereign immunity is not deemed appropriate, and state trading agencies are placed on an equal footing with other litigants. ${ }^{32}$

In the October 1972 Trade Agreement, the parties agreed that sovereign immunity will not be asserted on behalf of commercial instrumentalities of the U.S.S.R. and, of course, American organizations. The Agreement further provides that each party will accord the other the right to seek redress in its courts. This provision contains an interesting "jural most-favored-nation" clause to the effect that litigants shall enjoy the same rights in the courts of the forum party as would a similar litigant from any third country. ${ }^{33}$ Hence, U.S. trading interests may file, perhaps hesitantly, for Soviet adjudication of their rights. It also appears, therefore, with regard to the Soviet Union and presumably other recognized Soviet bloc governments, that no obstacles remain to prevent the recognition of state trading organizations as a proper party plaintiff or defendant in our courts.

The problem of the status of the instrumentalities of unrecognized governments before our courts appears reasonably settled. In Upright v. Mercury Business Machines Co., ${ }^{34}$ the courts of New York recognized the right of an assignee of an unrecognized government to sue. The plaintiff in $U$ pright had acquired a trade acceptance for value drawn on and accepted by the defendant who sought to escape payment on the grounds that the drawer was the instrumentality of the unrecognized East German government, and, therefore, lacked capacity to sue. The court never reached the question of whether the instrumentality of a non-recognized government could bring an action in its own name. In holding for the assignee of the acceptance, however, the court stated,

[i] the national government does not administratively forbid, or if it facilitates, the purchase and delivery ... of East German typewriters, ... the defendant buyer will be hard put to show the "illegality" of the underlying transaction, or the assignment, and thereby avoid payment. ${ }^{35}$

In the recent case of Carl Zeiss Stiftung v. VEB Carl Zeiss Jena, ${ }^{36}$ the West and East German Zeiss firms both sought title to the American "Zeiss" trademarks. While the West German firm was found to be the legal successor to the trademark rights, the claims of the East Germans were given full consideration without regard to its status as an instrumentality of a non-recognized government as urged by the plaintiffs.

The current governmental policy favoring the expansion of East-West trade

\footnotetext{
${ }^{32}$ See Fensterwald, United States Policies Toward State Trading, 24 Law \& Contemp. Pron. 369, $387-97$ (I959); Setser, The Immunities of the State and Government Economic Activities, 24 LAw \& ConteMr. Prob. 29 I (1959).

${ }^{38}$ US-USSR AGREEMENT, art. $7, \$ 2$.

${ }^{34}{ }_{3}$ App. Div. 2d 36,213 N.Y.S.2d 417 (Ig6r).

${ }^{85} I d$. at $4 \mathrm{I}, 213$ N.Y.S.2d at 423 .

so 433 F.2d 686 (2d Cir. I970).
} 
should be to maintain the integrity of foreign trade by providing access to our forums. With the normalization of East-West trade relations, the role of the courts in the settlement of disputes may be expected to increase as does the flow of commerce.

\section{III}

\section{Improvements in the Mechanism of Soviet-American Trade}

In addition to removing many of the legal obstacles thwarting East-West trade, the October I972 Trade Agreement includes provisions that will ease the myriad difficulties inherent in doing business in a distant and closed society. For instance, to establish an office in the Soviet Union an organization must be accredited. At the time of the signing of the Agreement, only two American firms in the fields of travel and tourism had been accredited. Under the Agreement, American business concerns will now be allowed accreditation and the right to employ Soviet personnel, use telecommunications equipment, and perform other necessary commercial functions. Furthermore, the Soviet Union now plans an expansive trade center including offices, a first-class hotel, and apartments. A later trade and exposition center is planned, wherein the United States may lease a pavilion for the display of its products. ${ }^{37}$

To guide American businessmen in their dealings with the Soviets, the United States will establish a commercial office in Moscow, which will serve to coordinate transactions with the various state trading agencies. The Soviet Union will, in turn, establish a trade representation in Washington to serve a liaison function similar to that of the American commercial office. ${ }^{38}$

Trading with a planned economy wherein prices and production are not determined by a market mechanism may result in severe market disruption. For example, if Russian razor blades were imported and sold at a price significantly below the prevailing domestic prices, the demand for these blades, presumably, would be very high. Were the Soviet Union a capitalistic nation, the lower price may be due to some natural competitive advantage in the razor blade production, such as a lower cost of capital, labor, or materials. The price of Soviet exports is not, however, derived from a market mechanism, but by a governmental determination. Therefore, a market disruption may not necessarily be based upon a competitive advantage, but merely an administrative pricing decision. For this reason, the U.S.-U.S.S.R. Trade Agreement incorporates an anti-market disruption provision to prevent the weakening of domestic markets from the "artificial" pricing of imports."

At the time of the signing of the October 1972 Trade Agreement, it was announced that the parties were progressing on copyright and tax treaties. Furthermore, a Joint U.S.-U.S.S.R. Commercial Commission has been established to monitor trade relations between the two countries. ${ }^{40}$

\footnotetext{
${ }^{37}$ White House Fact Sheet at 593.

${ }^{38}$ US-USSR AGREEMENT, art. 5 \& Annex 2-3.

${ }^{30}$ Id. art. 3 \& Annex I.

10 White House Fact Sheet at 595.
} 
Soviet foreign trade has been characterized, in the past, by its almost barter-like quality. ${ }^{41}$ Before a trade deal is signed, a would-be seller finds himself offered some commodity in exchange for part or all of his sales price. An arrangement of this sort, of course, lessens the Soviet need for hard currency and may help reduce domestic surpluses. Although the new Trade Agreement specifies payment is to be made in United States dollars or any other agreed upon currency, ${ }^{42}$ there is no reason to suspect sellers will not be pressured to exchange their products for Soviet goods. This philosophy of a non-monetary exchange may underlie the recent agreement between the Soviet Union and Occidental Petroleum, wherein a fertilizer plant will be built with American technology and payment will be made in the form of fertilizer. ${ }^{43}$ Obviously, the Soviets will prudently seek to barter wherever possible as it will serve their interests twofold-the increase of exports and the conservation of hard currency reserves.

\section{ConcLusion}

The October 1972 Trade Agreement has eliminated many of the hurdles that formerly stood in the path of normalized East-West trade relations. The passage of the proposed Trade Reform Act of 1973 would permit extension of most-favorednation status to the Soviet Union, and thereby terminate twenty-two years of economic discrimination.

Legislation and diplomatic accords will not, however, lead immediately to the flow of substantial trade. Understandably, each partner will be somewhat wary of the other initially and will avoid becoming overly dependent upon the exports of the other. Aside from whatever ideological qualms harbored by the American business community, the unfamiliarity of dealing with a state trading organization may deter all but the most sophisticated enterprises.

Although there are obvious difficulties to be overcome, the prospects for an era of improved East-West trade relations are excellent, and definitely skewed in favor of the United States.

\footnotetext{
11 PISAR 216.

'2 US-USSR AGREEMENT, art. 4.

(3 TIMIE, Apr. 23, 1973, at 72.
} 